УДК 336:378

doi: https://doi.org/10.33763/npndfi2020.04.034

Igor Lyutyy

Dr. Sc. (Economics), Professor, Taras Shevchenko National University of Kyiv,

Kyiv, Ukraine, liutyi@knu.ua

ORCID ID: https://orcid.org/0000-0002-3561-2432

Hlib Polianovskyi

PhD student, Taras Shevchenko National University of Kyiv,

Kyiv, Ukraine, g.polianovskyi@gmail.com

ORCID ID: https://orcid.org/0000-0001-5664-7207

\title{
FEATURES AND RESULTS OF FINANCING HIGHER EDUCATION INSTITUTIONS IN TERMS OF INTEGRATION PROCESSES (THE CASE OF UKRAINE AND NORWAY)
}

\begin{abstract}
This article considers the concept of internationalization of the higher education sector under the influence of globalization processes. In today's realm, it is difficult for higher education institutions to maintain sustainable development without international collaboration and cooperation. The example of such cooperation in the international arena is the Norwegian-Ukrainian partnership in the higher education sector. The article reviews the higher education funding system in Norway and highlights the incentives for Norwegian universities to enter into international partnerships. In this regard, two higher education projects between Ukraine and Norway are analyzed: Norwegian-Ukrainian cooperation in Public Sector Economy Education: Accounting, Budgeting and Finance (NUPSEE) and Norwegian-Ukrainian cooperation in the area of Public sector accounting, budgeting and finance Research Education (NUPRE). The vital part of such partnerships is potential perspectives for the Ukrainian universities, which are discussed in this paper. The main conclusion is that under current circumstances universities are faced with government funding cuts and they need to find alternative revenue streams. In this regard, internationalization can be an integral part in providing the Ukrainian universities with possibilities to search for alternative revenue sources for financing their activities.
\end{abstract}

Key w ords: internationalization, higher education sector, higher education funding, Ukrainian-Norwegian cooperation.

JEL classification: H52, I22.

\section{Лютий I. 0.}

доктор економічних наук, професор, завідувач кафедри фінансів Київського національного університету імені Тараса Шевченка, Київ, Україна, liutyi@knu.ua ORCID ID: https://orcid.org/0000-0002-3561-2432

\section{Поляновський Г. $A$.}

аспірант Київського національного університету імені Тараса Шевченка,

Київ, Україна, g.polianovskyi@gmail.com

ORCID ID: https://orcid.org/0000-0001-5664-7207

\section{ОСОБЛИВОСТІ ТА РЕЗУЛЬТАТИ ФІНАНСУВАННЯ ЗАКЛАДІВ ВИЩОЇ ОСВІТИ В УМОВАХ ІНТЕГРАЦІЙНИХ ПРОЦЕСІВ (ПРИКЛАД УКРАЇНИ І НОРВЕГІЇ)}

\begin{abstract}
Анотація. Розглянуто концепиію інтернаціоналізації сектору вищої освіти під впливом глобалізаційних процесів. У теперішніх реаліях закладам вишоі освіти (3ВО) важко підтримувати сталий розвиток без міжнародної співпраці та колаборації. Прикладом такого співробітниитва є норвезькоукраїнське партнерство. Висвітлено систему бінансування вищої освіти в Норвегії та стимули для норвезьких університетів вступати в міжнарод-
\end{abstract}

(с) Аютий I. О., Поляновський Г. А., 2020 
ні партнерські відносини. Проаналізовано два відповідні проекти між Україною і Норвегією: Norwegian-Ukrainian cooperation in Public Sector Economy Education: Accounting, Budgeting and Finance (NUPSEE) i Norwegian-Ukrainian cooperation in a field of Public sector accounting, budgeting and finance Research Education (NUPRE). Важливою складовою подібних проектів є перспективи для українських університетів. Зроблено висновок, шо за нинішніх обставин ЗВО стикаються зі скороченням державного фјнансування, $i$ їм потрібно шукати альтернативні потоки доходів. Тому інтернаціоналізація може стати невід'ємною частиною надання вітчизняним університетам можливостей пошуку джерел для бінансування їхноӥ діяльності.

К $\Lambda$ юч о в і с $\Lambda$ о в а : інтернаціоналізація, сектор вищої освіти, фінансування вищої освіти, українсько-норвезька співпраця.

Табц. 2. Рис. 1. Міт. 38.

Лютый И. А.

доктор экономических наук, профессор, заведующий кафедрой финансов Киевского национального университета имени Тараса Шевченко, Киев, Украина

Поляновский Г. А.

аспирант Киевского национального университета имени Тараса Шевченко, Киев, Украина

\title{
ОСОБЕННОСТИ И РЕЗУЛЬТАТЫ ФИНАНСИРОВАНИЯ УЧРЕЖДЕНИЙ ВЫСШЕГО ОБРАЗОВАНИЯ В УСЛОВИЯХ ИНТЕГРАЦИОННЫХ ПРОЦЕССОВ (ПРИМЕР УКРАИНЫ И НОРВЕГИИ)
}

\begin{abstract}
Аннотация Рассмотрена концепция интернационализации сектора высшего образования под влиянием глобализационных процессов. В нынешних реалиях высшим учебным заведениям трудно поддерживать устойчивое развитие без международного сотрудничества и колаборации. Примером такого сотрудничества является норвежско-украинском партнерство. Освещены система фонансирования высшего образования в Норвегии и стимуль для норвежских университетов вступать в международные партнерские отношения. Проанализированы два соответствующих проекта между Украиной и Норвегией: Norwegian-Ukrainian cooperation in Public Sector Economy Education: Accounting, Budgeting and Finance (NUPSEE) u NorwegianUkrainian cooperation in a field of Public sector accounting, budgeting and finance Research Education (NUPRE). Важной составляющей подобных проектов являтся перспективы для украинских университетов. Сделан вывод, что при нынешних обстоятельствах вузы сталкиваются с сокращением государственного бцнансирования, и им нужно искать альтернативные потоки доходов. Поэтому интернационализация может стать неотъемлемой частью предоставления отечественным университетам возможностей поиска источников для бинансирования их деятельности.

К $\Lambda$ ючев в е с $\Lambda$ о в а: интернационализация, сектор высшего образования, финансирование высшего образования, украинско-норвежское сотрудничество.
\end{abstract}

Higher education has always been seen as one of the most important and debatable areas in the public sector because of its vital role in socio-economic development and complexity $[1 ; 2]$. Higher education institutions (HEIs) are the "engine" or, in other words, ground for the sustainable development of "knowledge economy" [3;4]. The idea here is that knowledge is considered as a more significant element in economic development rather than materials because of its tight connection to technologies [5]. 
According to H. Gupta and N. Singhal [6], the main activities of HEIs can have significant impacts on social, economic and environmental areas. Undoubtedly, such effects are very complex, and they can be both positive and negative, direct and indirect, short-term and long-term [7]. F. Findler, N. Schönherr, R. Lozano, and D. Reider provide a very fruitful review of HEIs' impacts on sustainable development of a country, where the authors classify the main universities' impacts into different themes such as economic growth, change of the social and business culture, social interactions, contribution to the environmental changes, change of lifestyle and urbanization [8].

The higher education sector plays a decisive role in promoting the "Europe 2020 " strategy and driving forward the sustainable growth of the European continent [9]. One of the main targets of the "Europe 2020" strategic plan is that by $202040 \%$ of all young European population will have a tertiary education [9]. This aim is directly connected with the intention of the European Union (EU) to maintain its sustainable growth since higher education provides highly skilled citizens who consequently can apply for different valuable jobs. Therefore, the EU always support and promote higher education through a variety of programs such as "Erasmus+" and "Horizon 2020". Here one of the main objectives of EU's support for higher education is international cooperation, mobility and partnerships [10]. It is done in order to offer great opportunities for people to learn from different cultural dimensions, to work on joint international projects and to advance research.

Many universities across Europe have intentions to become well-known internationally and to be a part of the global education and research community [11]. Looking for the best practices, HEIs tend to globalization and convergence in order to maintain their sustainable growth [12]. According to Krucken et al., a global convergence influences individual universities to employ international frameworks in their activities [13]. Moreover, international engagement becomes an integral part of many HEIs' strategies, including the increase of international students [11], international projects and activities [12], and international joint degree programmes [14].

Many academics investigate a topic of financing the higher education sector, particularly identifying the effects of the international partnerships, cooperation and collaboration, namely, H. de Wit, J. Knight, P. G. Altbach, T. Iefymenko, I. Bohdan, S. Gasanov, I. Lyutyy, V. Geets and others. However, international cooperation always develops and refines, creating new ways of how to cooperate at the international level. In today's realm, HEI across the globe are faced with government funding cuts and therefore they need to search for alternative revenue streams. That is why internationalization can be of a great importance in providing HEIs with opportunities to find alternative revenue funds for financing their activities. In this regard, the paper examines two higher education partnerships between Ukraine and Norway which can serve as examples of the diversifying of revenue sources. Besides, the context of this study may be of great interest because of analysis of the higher education partnerships between the Nordic region country (Norway) and more exceptional the Central Eastern European country (Ukraine). According to the study done by D. Suspitsin [15], the context of post-Soviet 
countries is recognized as a new call for researchers in the analysis of transformations of the higher education sector.

There are plenty of rationales for universities to internationalize. In this regard, M. Seeber et al. developed a conceptual framework of factors that influence HEIs' intentions for internationalization [16]. The first rationale that was mentioned by authors is global student mobility. This corresponds to the fact that if students face different educational and cultural settings, they may become more open-minded and engaged citizens who are ready to work in diverse cultural environments [17]. Besides, internationalization may advance the curricula of different joint or doubledegree programs. When HEIs cooperate globally, they are able to refine programs' curricula to international requirements, promoting a higher quality of studying and attracting more international students [18]. Furthermore, internationalization enhances the quality of the education process, namely through the involvement of professors from different countries [19]. Sharing own experience between professors' circles is without doubts can benefit the quality of teaching processes [16].

The definition of internationalization has become widely used, and sometimes it includes broad meanings of different notions. The confirmation of such a statement is Knight's opinion that "internationalization is used to describe many phenomena at different levels and therefore is losing its original understanding" $[17$, p. 76]. Besides, H. de Wit confirmed that the concept of internationalization should be reconsidered and updated according to modern realities and settings [20]. Therefore, it is reasonable to provide some notions which are used globally to define what internationalization particularly means. According to three wellknown international organizations the National Association of Foreign Student Advisers (NAFSA), the International Association of Universities (IAU), and the European Association of International Education (EAIE), many possible elements can be considered as internationalization, including international student mobility, research cooperation, extra-curricular studies, and cross-country initiatives such as both face-to-face and distance joint programs, and double-degree programs [21]. In this paper, the notion of internationalization mostly refers to double-degree programs which will be analyzed further in this paper.

Total government spending on higher education as a percentage of total government spending in Ukraine has been decreasing since 2013, as well as total government spending on higher education as a percentage of GDP (Table 1). This creates a necessity for the Ukrainian HEIs to diversify their revenue streams in order to sustainably maintain their operations. Under such circumstances, universities are more inclined to change their strategies in order to find appropriate funding of their operations and this process is called financialization of universities'

Table 1

Public funding of higher education in Ukraine

\begin{tabular}{|c|c|c|c|c|c|}
\hline Indicator & 2013 & 2014 & 2015 & 2016 & 2017 \\
\hline Total government spending on higher education & & & & & \\
as a percentage of total government spending & 6,0 & 5,6 & 4,9 & 4,4 & 3,7 \\
as a percentage of GDP & 2,1 & 1,8 & 1,5 & 1,9 & 1,3 \\
\hline
\end{tabular}

So urce: compiled by the author based on [23]. 
missions [22]. The financialization of HEIs' missions includes globalization and internationalization processes. The latter is the focus of this paper since the internationalization can provide universities with alternative revenue sources. In this regard, the paper examines two higher education partnerships between Ukraine and Norway which can supplement financing process of two universities.

Before going to particular examples of this paper, it is reasonable to examine the most well-known international project such as Erasmus+. Erasmus+ is a considerable international programme to promote education in Europe with a budget of $€ 14.7$ billion in 2020 that support around 2 million students in the higher education sector. The size of this program can not be overestimated since it includes approximately 25 thousand students in joint master's degrees with around 800 thousand teachers in staff mobility. Besides, more than 150 knowledge alliances initiated by 1500 HEIs and companies [24]. Erasmus+ Programme includes many actions and subprograms, namely Action 1 (Mobility of learners and staff, Erasmus Mundus Joint Master Degrees, Erasmus+ Master Loans), Action 2 (Strategic Partnerships, Knowledge Alliances, Sector Skills Alliances, Capacity-building), Action 3 (Knowledge in the fields of education, training and youth, Support to European policy tools, Cooperation with international institutions, Stakeholder dialogue, policy and Programme promotion), Jean Monnet activities (Academic Modules, Chairs, Centres of Excellence, Policy debate with the academic world, Support to associations), and Sports activities (Collaborative Partnerships, Notfor-profit European sport events, Strengthening of the evidence base for policymaking, Dialogue with relevant European stakeholders) [25]. Because of the purpose of this paper, it is interesting to take a look at Erasmus Mundus Joint Master Degree (EMJMD) subprogram which is an integrated international education programme delivered by the unified group of HEIs. The idea here is that universities joint their separate programmes in one programme in order to improve the attractiveness, foster performance, and refine the studying process.

There are not as many reports that analyze the impacts of EMJMD, but a fruitful report was done by B. Terzieva and M. Unger [14], including a graduate impact survey (GIS). Undoubtedly, it is vital to understand what actual impacts are connected to students' postgraduate life and how they are satisfied with the programme. Considerably, over 1 thousand students participated in the survey, and the highest portion of them have already finished EMJMD.

Firstly, it is essential to examine how students were satisfied with EMJMD programmes. In general, more than $77 \%$ of graduates are satisfied with Erasmus Mundus, highlighting the attitude towards international students, an appropriate level of needed facilities, and professional teaching staff [14]. However, many learners stated that teaching supervision and support, studying guidance, and student networking might be improved. It goes without saying that it is not easy for foreign students in some cases to establish networks with native students without the assistance of the university. This is also the case with teaching supervision since foreign students do not have strong social connections with native teaching staff.

Going further, it is crucial to discover the main impacts of EMJMD programmes on the postgraduate life of students. One of the most significant impacts that were defined by the survey is gained intercultural competencies [14]. Obviously, 
intercultural competencies are vital for career development in the period of globalized labour markets. Therefore, more than $50 \%$ of Erasmus Mundus graduates stated that they are satisfied with the level of preparedness to the labour market. However, students highlight that the programme could be improved by the increasing networking with potential employers (49\%), career supervision (49\%), and focusing more on the practical part of the studying process (31\%) [14]. With such fulfilment to preparedness to the labour market, it is not surprising that $85 \%$ of graduates found a job within six months after graduation [14]. Overall, according to the study done by B. Terzieva and M. Unger, students have positive feelings about the programme, and they highlight a considerable impact on their career development, international networking, and life experience [14].

In order to analyze two higher education projects between Ukraine and Norway, namely Norwegian-Ukrainian cooperation in Public Sector Economy Education: Accounting, Budgeting and Finance (NUPSEE) and Norwegian-Ukrainian cooperation in a field of Public sector accounting, budgeting and finance Research Education (NUPRE), it is reasonable to look at the context in which these projects exist. In this regard, the question arises: what are the incentives for Norwegian HEI (Nord University) to cooperate internationally with Ukrainian partner (Taras Shevchenko National University of Kyiv)? To understand the incentives, it is crucial to explore the main features of the funding system that is employed in Nord University. The funding model of any university has significant impacts on both its behaviour and strategical development [2]. Therefore, the examination of the funding model is an inevitable process in understanding HEI's behaviour [26]. Moreover, according to Figure, it can be concluded that, although the share of higher education expenditure in different EU countries varies, on average, public funding in OECD and EU countries remains the main type of funding for the higher education sector. Consequently, a government has a considerable influence on how universities will operate and strategically develop under the different funding model characteristics.

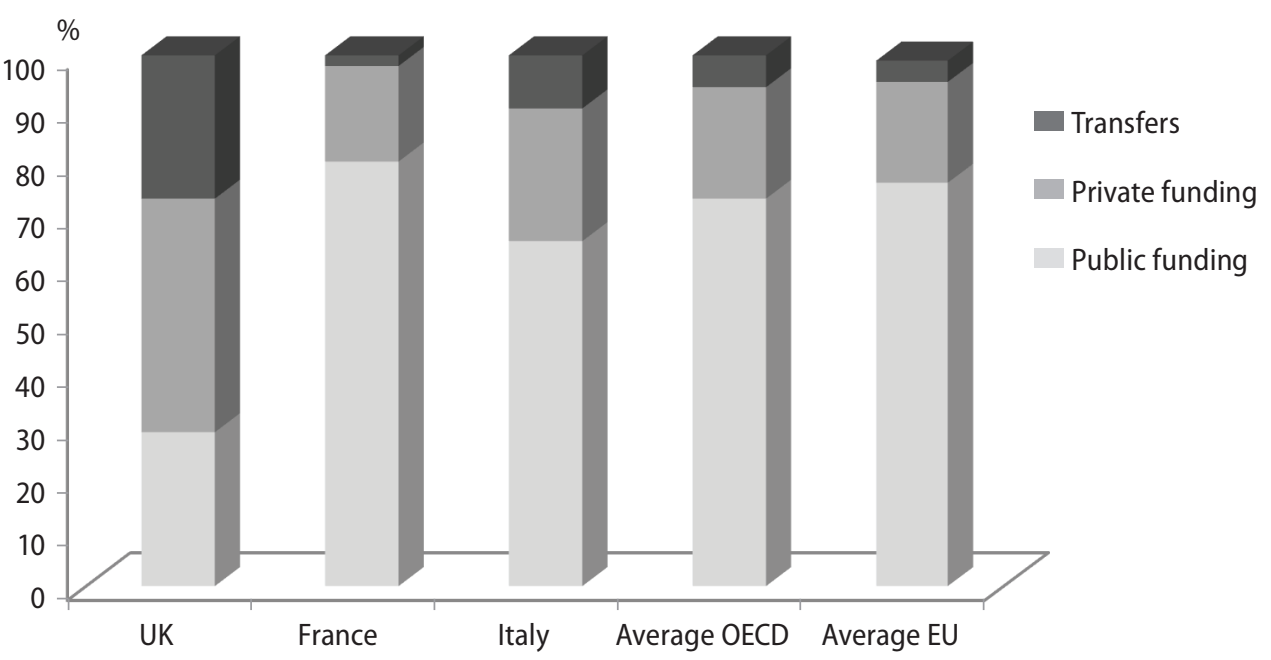

Figure. Expenditures on higher education in some EU countries in 2018

Source: compiled by the author according to [27]. 
The Norwegian higher education sector has started to develop back in the 1950s with the introduction of the Norwegian welfare state model [28]. This model opened educational entities for society and defined that every individual has a right to access all education levels. After that, the higher education sector in Norway has grown, and demand for the reforming process has occurred.

In Norway, national commissions play a considerable role in the policy-making processes. The idea here is that the Ministry of Education and Research set a national commission to address a particular problem that should be resolved. After the analysis of a particular issue, the commission creates a report that can be regarded as a white paper, debating about how the Norwegian higher education sector could cope with a particular problem. One of such commissions, namely Mjøs commission, issued a report that formed the ground for one of the most significant reforms in the Norwegian higher education sector - the Quality Reform 2002 [28].

The Quality Reform reviewed a complex set of issues, containing organizational, structural, financial and quality aspects [29]. The reform resulted in an increase of both institutional and financial autonomy, in the modernization of a new governance model, in increasing of the internationalization process, and in the implementation of the new funding model that comprises of a basic component (70\%) and performance-based component (30\%) [30]. The funding model that was introduced as a part of the Quality Reform has been currently using. The difference between the older model and the current one is that the older model was mostly based on the input criteria (e.g. the number of enrolled students), but the new model is mostly based on performance and results.

The Norwegian Ministry of Education and Research distributes a block grant financing to each university annually [31]. The board of each university defines the main priorities of the institution, but priorities should be in line with a national strategy [31]. In this regard, each HEIs has significant autonomy in the process of the allocation of public funds. As it was mentioned earlier, the block grant consists of two parts: a fixed component and result-based component. The relationship between fixed funds and result-based allocations can vary between different HEIs [32]. For this reason, the university board considers to what extent the national performance incentives for three core activities (education, research, and cooperation with society and business) would be applied in the internal allocation system. Besides, the university board defines whether the university needs to create additional performance incentives to promote its aims and strategies [32]. Finally, the amount of the fixed component for each university depends on a history of specific targets set by the government over time, including today's fixed component - funding per institution [31].

The Norwegian funding model for higher education has been developing since the Quality Reform. The Norwegian Ministry of Education and Research has presented the latest change in 2017. The Ministry introduced some refinements to the result-based component, including some new performance indicators. In this regard, performance-based funding has become a result of eight quantitative indicators that measure the performance of every HEIs (Table 2).

According to Table 1, the first four indicators have an open-end budget, meaning that the better the results, the more funding the institutions can get, regardless of 
Table 2

Eight quantitative indicators that are related to the result-based component

\begin{tabular}{|c|l|c|}
\hline No. & \multicolumn{1}{|c|}{ Indicator } & Framework \\
\hline 1 & Number of credits & Opened \\
2 & Number of exchange students (including Erasmus+) & Opened \\
3 & Number of graduates & Opened \\
4 & Number of doctoral candidates & Opened \\
5 & Funds from the EU & Closed \\
6 & Funds from Norway Research Council and Regional Research Fund & Closed \\
7 & Income from grant and commission activities (BOA) & Closed \\
8 & Number of scientific publications (publication points) & Closed \\
\hline
\end{tabular}

Source: compiled by the author based on [32].

the performance of other universities. The last four indicators have a closed-end budget, which means that the universities compete about a fixed amount of financing. From Table 1, the second indicator, namely "Number of exchange students (including Erasmus+)" plays a significant role because this indicator is open-ended, meaning that HEIs will increase its value in order to gain more funding. Therefore, Norwegian universities aim to increase the number of international partnerships and cooperation in order to receive more money from the government. The two higher education projects between Ukraine and Norway, which are analyzed in this paper, are not exceptions.

The first project is the Norwegian-Ukrainian cooperation in Public Sector Economy Education: Accounting, Budgeting and Finance (NUPSEE) that started in 2016. The Nord University Business School received a grant from The Norwegian Agency for International Cooperation and Quality Enhancement in Higher Education (DIKU). The purpose of this grant funding is the support of higher education and research cooperation between Norway represented by Nord University and Ukraine represented by the Taras Shevchenko National University of Kyiv [33]. However, the cooperation between Norway and Ukraine started before the NUPSEE back in 2014 when Nord University signed the agreement with 13 Ukrainian universities that are members of Norwegian-Ukrainian University Alliance (NUUA). The target of this agreement stands for strengthening the national cooperation in the field of Public Sector Finance between all members of NUUA.

Talking about the NUPSEE programme, it is essential to highlight its main vectors, including [33]:

1. Students mobility between Norway and Ukraine;

2. Collaboration in research field by strengthening joint research projects between $\mathrm{PhD}$ researchers;

3. Networking on all levels of education (individual, faculty, university, and national) in order to faster the integration of Ukraine into the European society.

Two groups have already graduated from the NUPSEE double-degree programme. The graduates received two Master degree diplomas from Nord University and the Taras Shevchenko National University of Kyiv. In this regard, 
the graduates can increase their competitive advantage in the labour market, and enhance international networking and cooperation. However, future research should be done in order to evaluate the particular impacts of this cooperation on graduates' career development, global networking, and life experience.

The second project is the Norwegian-Ukrainian cooperation in a field of Public sector accounting, budgeting and finance Research Education (NUPRE) which focuses on the development of joint academic collaboration at the $\mathrm{PhD}$ level. The idea here is that students can enter a double-degree programme at the $\mathrm{PhD}$ level and after the completion receive two PhD diplomas: one in Ukraine and one in Norway [34]. This project is also granted from the DIKU as a continuation of NUPSEE programme but on a higher level. The main objectives of this programme are the development and harmonization of the content of the Ukrainian $\mathrm{PhD}$ programme, advancement of research competencies according to international requirements, and strengthening the partnership between universities. Interestingly, the programme is based on "cotutelle" philosophy that means "co-supervision". This particularly means that $\mathrm{PhD}$ student signs an agreement with two HEIs which will supervise the candidate. The agreement also contains requirements regarding enrollment and evaluation of candidate's studying process and dissertation [35]. As it was mentioned earlier, it will be crucial to evaluate the real impacts of this cooperation and to survey future graduates about the effectiveness and outcomes of the programme.

The programmes have a potential according to the report done by B. Terzieva and M. Unger [14], including the GIS that highlights positive impacts on graduates' career development, international networking, and life experience. However, a current context under the influence of COVID-19 pandemic should be taken into consideration since it can provoke many issues that can negatively reflect international joint mobility programmes [36]. For instance, according to the survey done by EACEA about the EMJMD implementation in the context of COVID-19, many obstacles and issues should be addressed in order to maintain the international joint mobility projects such as [36]:

1) visa and travel limitations;

2) university services (e.g. enrolment requirements, support with accommodation provision);

3) health conditions of students and personnel;

4) mode of studying (move to distance and online learning).

Undoubtedly, the mentioned challenges can slower international cooperation, but universities need to draw attention to them and provide strategic responses.

Notwithstanding challenges that may occur in the current context, international partnerships and cooperation between Ukraine and Norway in the higher education sector can be valuable for both sides. However, it reasonable to pay more attention to the advantages of such cooperation specifically for the Ukrainian side based on the purposes of this article. Firstly, the Ukrainian-Norwegian partnership can be beneficial for the quality of the Ukrainian education process, by harmonizing studying process to international requirements [37], the advancement of educational programmes with the support of foreign academics, and development of international events (e.g. conferences, campus events, workshops) [19]. Secondly, 
the cooperation can strengthen institutional research capacity by joining and complementing research resources, skills and knowledge in order to produce quality international research output [12]. Furthermore, such partnerships can serve as a positive strategic intention to enhance the university's reputation at the national and international levels [20]. Increasing HEI's prestige has become a crucial issue because of the importance of international ranking systems. Moreover, the development of international strategic partnerships may encourage synergy effects, benefits from collective efforts in terms of funding savings and investments [16]. Finally yet importantly, international collaboration may have a positive impact on researchers' networks beyond the national context, which can increase the scope of the research agenda [20].

To conclude, internationalization plays a decisive role in the sustainable development of the universities under the current globalized context. International cooperation is gaining more attention as a vital element of many HEIs' strategies, embracing the rise of international student mobility [11], multinational projects and other studying activities [12], and international joint degree programmes [14]. In this regard, the aim of this paper is to review some examples of such international cooperation, specifically the NUPSEE and NUPRE partnerships between Ukraine and Norway, and also to discover the perspectives of these partnerships for Ukrainian universities.

Nowadays, HEI are faced with government funding cuts and are inclined to search for alternative revenue sources, while at the same time seeking cost efficiencies in their operations [38]. Internationalization can play a decisive role in providing the Ukrainian HEIs with possibilities to find alternative revenue streams for financing their activities. In this regard, the paper examines two higher education partnerships between Ukraine and Norway which can serve as examples of the diversifying of revenue sources.

Both programmes have a potential for sustainable development of both universities, namely Nord University and the Taras Shevchenko National University of Kyiv. For the latter side, such partnerships can improve the quality of the studying process, taking into consideration the convergence to the international educational requirements. Besides, such cooperation can refine the Ukrainian studying programmes with updated educational agenda through the involvement of international academic circles. In addition, international collaboration can reinforce research activities by combining resources, efforts and knowledge from both sides of the collaboration. Undoubtedly, international partnerships can also promote the university's reputation and prestige that become vital elements in the higher education sector with the expansion of ranking system value. Last but not least, international cooperation enhances a networking process among students and academics that positively influences international attitudes, the scope of research agenda, and intercultural communication.

Notwithstanding a diversity of the potential perspectives of mentioned partnerships, they should be evaluated from the student perspective as it was done by $B$. Terzieva and M. Unger, when the academics conducted the graduate impact survey. Therefore, it is reasonable for further researchers of this topic to pay due attention to how such partnerships influence graduates' career development, 
international communication, and life experience. Conducting surveys among graduates of NUPSEE and NUPRE programmes can help to identify the real values of mentioned projects and to understand some points that should be improved or added.

Despite many benefits and perspectives that may occur because of the analyzed partnerships, some challenges take place under the context of COVID-19 pandemic. Without any doubts, these challenges should be taken into consideration since they have considerable impacts on peoples' lives which we can currently observe. The pandemic provokes many obstacles that should be addressed in order to maintain the international joint programmes such as visa and travel limitations, provision of university services, state of health of students and university personnel, changing the mode of education (from face-to-face to distance learning).

\section{References}

1. Reed, M., \& Meek, L. (2002). Introduction to Governing Higher Education: National Perspectives on Institutional Governance, 15-31. Dordrecht: Kluwer.

2. Frølich, N., Kalpazidou Schmidt, E., \& Rosa, M. (2010). Funding systems for higher education and their impacts on institutional strategies and academia: A comparative perspective. International Journal of Educational Management, 24 (1), 7-21. DOI: 10.1108/09513541011013015.

3. Johnstone, D. B., Arora, A., \& Experton, W. (1998). The financing and management of higher education: a status report on worldwide reforms. Washington, DC: World Bank.

4. Powell, W. W., \& Snellman, K. (2004). The knowledge economy. Annual Social Review, 30, 199-220. DOI: 10.1146/annurev.soc.29.010202.100037.

5. Hlib, P., Zatonatska, T., \& Liutyi, I. (2019). Utilization of Information Technologies in Higher Education. 2019 IEEE International Conference on Advanced Trends in Information Theory (ATIT), 349-354. DOI: 10.1109/ATIT49449.2019.9030449.

6. Gupta, H., \& Singhal, N. (2017). Framework for embedding sustainability in business schools: a review. Vision: The Journal of Business Perspective, 21 (2), 195-203. DOI: $10.1080 / 21568235.2015 .1044545$.

7. Lebeau, Y., \& Cochrane, A. (2015). Rethinking the 'third mission': UK universities and regional engagement in challenging times. European Journal of Higher Education, 5 (3), 250-263. DOI: $10.1080 / 21568235.2015 .1044545$.

8. Findler, F., Schönherr, N., Lozano, R., Reider, D., \& Martinuzzi, A. (2019). The impacts of higher education institutions on sustainable development. International Journal of Sustainability in Higher Education, 20 (1). DOI: 10.1108/IJSHE-07-2017-0114.

9. European Commission (2010). Europe 2020 - A European strategy for smart, sustainable and inclusive growth. Retrieved from https://ec.europa.eu/eu2020/pdf/ COMPLET\%20EN\%20BARROSO\%20\%20\%20007\%20-\%20Europe\%202020\%20-\%20 EN\%20version.pdf.

10. European Commission (2017). Communication on a renewed EU agenda for higher education, Communication from the Commission to European Parliament. Retrieved from https://eur-lex.europa.eu/legal-content/EN/TXT/?uri=CELEX\%3A52017DC0247.

11. Parker, L. D. (2012). From privatised to hybrid-corporatised higher education: A global financial management discourse. Financial Accountability \& Management, 28 (3), 247-268. DOI: 10.1111/j.1468-0408.2012.00544.x.

12. Altbach, P. G., \& Knight, J. (2007). The internationalization of higher education: Motivations and realities. Journal of Studies in International Education, 11 (3), 290-305. DOI: $10.1177 / 1028315307303542$. 
13. Krucken, G., Castor, C., Kosmutzky, A., \& Torka, M. (Eds.) (2006). Towards a Multiversity? Universities Between Global Trends and National Traditions, 7-16. Bielefeld. DOI: $10.14361 / 9783839404683-001$.

14. Terzieva, B., \& Unger, M. (2019). Erasmus Mundus Joint Master Graduate Impact Survey 2018 (Research Report). Vienna: Institute for Advanced Studies.

15. Suspitsin, D. (2007). Between the state and the market: sources of sponsorship and legitimacy in Russian non-state higher education. Private Higher Education in PostCommunist Europe, 157-178. Springer. DOI: 10.1057/9780230604391_8.

16. Seeber, M., Cattaneo, M., Huisman, J., \& Paleari, S. (2016). Why do higher education institutions internationalize? An investigation of the multilevel determinants of internationalization rationales. Higher Education, 72, 685-702. DOI: 10.1007/s10734-015-9971-x.

17. Knight, J. (2014). Is internationalisation of higher education having an identity crisis? The forefront of international higher education: A festschrift in honour of Philip G. Altbach, 75-87. Dordrecht: Springer Science \& Business Media.

18. Luijten-Lub, A. (2007). Choices in internationalisation. How higher education institutions respond to internationalisation, Europeanisation, and globalization. Enschede: CHEPS.

19. Hudson, R. (2015). Dominated by economics? Evidence of changing drivers of internationalization and its funding within higher education institutions in Europe. Higher Education Policy, 29 (1). DOI: 10.1057/hep.2015.4.

20. De Wit, H. (2014). The different faces and phases of internationalisation of higher education. The forefront of international higher education: A festschrift in honour of Philip G. Altbach, 89-99. Dordrecht: Springer Science \& Businss Media. DOI: 10.1007/978-94007-7085-0_6.

21. Buckner, E., \& Stein, S. (2020). What Counts as Internationalization? Deconstructing the Internationalization Imperative. Journal of Studies in International Education, 24 (2), 151-166. DOI: 10.1177/1028315319829878.

22. The State Treasury Service of Ukraine. (2020). Retrieved from https://www.treasury. gov.ua/ua/file-storage/2020-11.

23. Parker, L. D. (2012). From privatized to hybrid-corporatized higher education: A global financial management discourse. Financial Accountability E Management, 28 (3), 247-268. DOI: 10.1111/j.1468-0408.2012.00544.x.

24. European Commission (2020). Erasmus + Key Figures. Retrieved from https:// ec.europa.eu/programmes/erasmus-plus/about/key-figures_en.

25. European Commission (2020). Erasmus + Programme Guide. Retrieved from https://ec.europa.eu/programmes/erasmusplus/sites/erasmusplus2/files/erasmus_programme_ gui de_2020_v3_en.pdf.

26. Liutyi, I., Beliavskaiya, O., \& Polianovskyi, H. (2020). Financial autonomy of universities: historical overview and international experience. Scientific notes of Ostrog Academia National University, Economics, 18 (46), 68-78. DOI: 10.25264/2311-5149-202018(46)-68-78 [in Ukrainian].

27. OECD. (2020). Education at a Glance 2020: OECD Indicators. Paris: OECD Publishing. Retrieved from https://www.oecd.org/education/education-at-a-glance/.

28. Kwiek, M., \& Maassen, P. (2012). National higher education reforms in a European context: Comparative reflections on Poland and Norway. Frankfurt: New York: Peter Lang. DOI: $10.3726 / 978-3-653-02379-4$.

29. Stortingsmelding. (2000-2001). Gjør din plikt - Krev din rett (Kvalitetsreform av høyere utdanning. Tilrådning fra Utdannings - og forskningsdepartementet av 9. mars godkjent i statsråd samme dag. St. meld. nr. 27) [in Norwegian].

30. OECD. (2005). OECD Thematic review of tertiary education. Country background report for Norway. Paris: The Norwegian Ministry of Education and Research: OECD Publishing.

Наукові праці НДФІ • 2020 • № 4 (93) 
31. EACEA. (2020). National Policies Platform. Retrieved from https://eacea.ec.europa. $\mathrm{eu} /$ national-policies/eurydice/content/higher-education-funding-54_en\#: :text= Norwegian\%20students\%20are\%20entitled\%20to,study\%20at\%20least\%20half\%20time.

32. MoER. (2019). Information on the state budget of 2019 for universities and university colleges. Goals for universities and university colleges, budget and changes in funding and financing system. Retrieved from https://www.regjeringen.no/en/dep/kd/id586/.

33. Nord University. (2020). Norwegian-Ukrainian cooperation in Public Sector Economy Education: Accounting, Budgeting and Finance (NUPSEE). Retrieved from https://www. nord.no/no/om-oss/fakulteter-og-avdelinger/handlshogskolen/Sider/nupsee.aspx\#\&acd= fd83ab63-ec3c-8068-3cde-4968d8f2a975.

34. Nord University. (2020). Norwegian-Ukrainian cooperation in a field of Public sector accounting, budgeting and finance Research Education (NUPRE). Retrieved from https:// www.nord.no/no/om-oss/fakulteter-og-avdelinger/handelshogskolen/Sider/Nupre.aspx.

35. Nord University, \& Taras Shevchenko National University of Kyiv. (2020). Guidelines for joint academic supervision and collaboration on the education of PhD candidates. Retrieved from https://www.nord.no/no/om-oss/fakulteter-og-avdelinger/handelshogs kolen/Documents/Guidelines_joint_supervision_22.10.pdf.

36. EACEA. (2020). Survey Report Erasmus Mundus Programme Implementation in the Context of COVID-19. Retrieved from https://eacea.ec.europa.eu/sites/eacea-site/files/ brochure_surveyreporterasmusmundusprogrammecovid19_03.pdf.

37. Taylor, J. (2004). Towards a strategy of internationalization: Lessons and practice from four universities. Journal of Studies in International Education, 8 (2), 149-171. DOI: $10.1177 / 1028315303260827$.

38. Iefymenko, T., Gasanov, S., \& Bohdan, I. (2018). Public budget expenditures for higher education: structural changes and he problem of formular distribution. Bulletin of Kyiv National University of Technology and Design "Economic Sciences Series", materials of the VIII International scientific-practical conference (October 5, 2018, Kyiv), 27-51 [in Ukrainian].

\section{Список використаних Ажерем}

1. Reed M., Meek L. Introduction to Governing Higher Education: National Perspectives on Institutional Governance. Dordrecht : Kluwer, 2002. P. 15-31

2. Frølich N., Kalpazidou Schmidt E., Rosa M. (2010). Funding systems for higher education and their impacts on institutional strategies and academia: A comparative perspective. International Journal of Educational Management. 2010. Vol. 24 (1). P. 7-21. URL: https://doi.org/10.1108/09513541011013015.

3. Johnstone D. B., Arora A., Experton W. The financing and management of higher education: a status report on worldwide reforms. Washington, DC: World Bank, 1998. 33 p.

4. Powell W. W., Snellman K. The knowledge economy. Annual Social Review. 2004. Vol. 30. P. 199-220. URL: https://doi.org/10.1146/annurev.soc.29.010202.100037.

5. Hlib P., Zatonatska T., Liutyi I. Utilization of Information Technologies in Higher Education. 2019 IEEE International Conference on Advanced Trends in Information Theory (ATIT). 2019. P. 349-354. URL: https://doi.org/10.1109/ATIT49449.2019.9030449.

6. Gupta H., Singhal N. Framework for embedding sustainability in business schools: a review. Vision: The Journal of Business Perspective. 2017. Vol. 21 (2). P. 195-203. URL: https://doi.org/10.1080/21568235.2015.1044545.

7. Lebeau Y., Cochrane A. Rethinking the 'third mission': UK universities and regional engagement in challenging times. European Journal of Higher Education. 2015. Vol. 5 (3). P. 250-263. URL: https://doi.org/10.1080/21568235.2015.1044545. 
8. The impacts of higher education institutions on sustainable development / F. Findler, N. Schönherr, R. Lozano et al. International Journal of Sustainability in Higher Education. 2019. Vol. 20 (1). URL: https://doi.org/10.1108/IJSHE-07-2017-0114.

9. Europe 2020 - A European strategy for smart, sustainable and inclusive growth / European Commission. 2010. URL: https://ec.europa.eu/eu2020/pdf/COMPLET\%20 EN\%20BARROSO\%20\%20\%20007\%20-\%20Europe\%202020\%20-\%20EN\%20version.pdf.

10. Communication on a renewed EU agenda for higher education, Communication from the Commission to European Parliament / European Commission. 2017. URL: https:// eur-lex.europa.eu/legal-content/EN/TXT/?uri=CELEX\%3A52017DC0247.

11. Parker L. D. From privatised to hybrid-corporatised higher education: A global financial management discourse. Financial Accountability E Management. 2012. Vol. 28 (3). P. 247-268. URL: https://doi.org/10.1111/j.1468-0408.2012.00544.x.

12. Altbach P. G., Knight J. The internationalization of higher education: Motivations and realities. Journal of Studies in International Education. 2007. Vol. 11 (3). P. 290-305. URL: https://doi.org/10.1177/1028315307303542.

13. Towards a Multiversity? Universities Between Global Trends and National Traditions / ed. by G. Krucken, C. Castor, A. Kosmutzky, M. Torka. Bielefeld , 2006. P. 7-16. URL: https://doi.org/10.14361/9783839404683-001.

14. Terzieva B., Unger M. Erasmus Mundus Joint Master Graduate Impact Survey 2018 (Research Report). Vienna : Institute for Advanced Studies, 2019. 59 p.

15. Suspitsin D. Between the state and the market: sources of sponsorship and legitimacy in Russian non-state higher education. Private Higher Education in Post-Communist Europe. Springer, 2007. P. 157-178. URL: https://doi.org/10.1057/9780230604391_8.

16. Why do higher education institutions internationalize? An investigation of the multilevel determinants of internationalization rationales / M. Seeber, M. Cattaneo, J. Huisman, S. Paleari. Higher Education. 2016. Vol. 72. P. 685-702. URL: https://doi. org/10.1007/s10734-015-9971-x.

17. Knight J. Is internationalisation of higher education having an identity crisis? The forefront of international higher education: A festschrift in honour of Philip G. Altbach. Dordrecht : Springer Science \& Business Media, 2014. P. 75-87.

18. Luijten-Lub A. Choices in internationalisation. How higher education institutions respond to internationalisation, Europeanisation, and globalization. Enschede : CHEPS, 2007. 269 p.

19. Hudson R. Dominated by economics? Evidence of changing drivers of internationalization and its funding within higher education institutions in Europe. Higher Education Policy. 2015. Vol. 29 (1). URL: https://doi.org/10.1057/hep.2015.4.

20. Wit $H$., de. The different faces and phases of internationalisation of higher education. The forefront of international higher education: A festschrift in honour of Philip G. Altbach. Dordrecht : Springer Science \& Businss Media, 2014. P. 89-99. URL: https://doi.org/ 10.1007/978-94-007-7085-0_6.

21. Buckner E., Stein S. What Counts as Internationalization? Deconstructing the Internationalization Imperative. Journal of Studies in International Education. 2020. Vol. 24 (2). P. 151-166. URL: https://doi.org/10.1177/1028315319829878.

22. Аержавна казначейська служба України. 2020. URL: https://www.treasury.gov. ua/ua/file-storage/2020-11.

23. Parker L. D. From privatized to hybrid-corporatized higher education: A global financial management discourse. Financial Accountability \& Management. 2012. Vol. 28 (3). P. 247-268. URL: https://doi.org/10.1111/j.1468-0408.2012.00544.x.

24. Erasmus+ Key Figures / European Commission. 2020. URL: https://ec.europa.eu/ programmes/erasmus-plus/about/key-figures_en. 
25. Erasmus+ Programme Guide / European Commission. 2020. URL: https://ec.europa. eu/programmes/erasmusplus/sites/erasmusplus2/files/erasmus_programme_gui de_2020_ v3_en.pdf.

26. Аютий I. О., Білявська О. Б., Поляновський Г. А. Фінансова автономія університетів: історичний огляА та міжнародний досвіА. Наукові записки Національного університету “Острозька академія”. Сер.: Економіка. 2020. № 18 (46). С. 68-78. URL: https://doi.org/10.25264/2311-5149-2020-18(46)-68-78.

27. Education at a Glance 2020: OECD Indicators / OECD. Paris : OECD Publishing, 2020. URL: https://www.oecd.org/education/education-at-a-glance/.

28. Kwiek M., Maassen P. National higher education reforms in a European context: Comparative reflections on Poland and Norway. Frankfurt ; New York : Peter Lang, 2012. URL: https://doi.org/10.3726/978-3-653-02379-4.

29. Gjør din plikt - Krev din rett (Kvalitetsreform av høyere utdanning. Tilrådning fra Utdannings - og forskningsdepartementet av 9. mars godkjent i statsråd samme dag. St. meld. nr. 27) / Stortingsmelding. 2000-2001 [in Norwegian].

30. OECD Thematic review of tertiary education. Country background report for Norway / OECD. Paris : The Norwegian Ministry of Education and Research: OECD Publishing, 2005. 98 p.

31. National Policies Platform / EACEA. 2020. URL: https://eacea.ec.europa.eu/national policies/eurydice/content/higher education funding 54_en\#: :text=Norwegian\%20 students\%20are\%20entitled\%20to,study\%20at\%20least\%20half\%20time.

32. Information on the state budget of 2019 for universities and university colleges. Goals for universities and university colleges, budget and changes in funding and financing system / MoER. 2019. URL: https://www.regjeringen.no/en/dep/kd/id586/.

33. Norwegian-Ukrainian cooperation in Public Sector Economy Education: Accounting, Budgeting and Finance (NUPSEE) / Nord University. 2020. URL: https://www. nord.no/no/om oss/fakulteter og avdelinger/handlshogskolen/Sider/nupsee. aspx\#\&acd=fd83ab63 ec3c 8068 3cde 4968d8f2a975.

34. Norwegian-Ukrainian cooperation in a field of Public sector accounting, budgeting and finance Research Education (NUPRE) / Nord University. 2020. URL: https://www. nord.no/no/om oss/fakulteter og avdelinger/handelshogskolen/Sider/Nupre.aspx.

35. Guidelines for joint academic supervision and collaboration on the education of PhD candidates / Nord University, Taras Shevchenko National University of Kyiv. 2020. URL: https://www.nord.no/no/omoss/fakulteter og avdelinger/handelshogskolen/ Documents/Guidelines_joint_supervision_22.10.pdf.

36. Survey Report Erasmus Mundus Programme Implementation in the Context of COVID-19 / EACEA. 2020. URL: https://eacea.ec.europa.eu/sites/eacea site/files/brochure surveyreporterasmusmundusprogrammecovid19_03.pdf.

37. Taylor J. Towards a strategy of internationalization: Lessons and practice from four universities. Journal of Studies in International Education. 2004. Vol. 8 (2). P. 149-171. URL: https://doi.org/10.1177/1028315303260827.

38. Єбименко T. I., Гасанов С. С., Богдан I. В. Видатки державного бюджету на вищу освіту: структурні зміни та проблема формульного розподіку. Вісник Київського національного університету технологій та дизайну. Сер.: Економічні науки. 2018. Спецвип.: Ефективність організаційно-економічного механізму інноваційного розвитку вищої освіти України : матеріали VIII Міжнар. наук.-практ. конф. (5 жовтня 2018 р., м. Київ). С. 27-51. 